\title{
Growth Dynamics and Water Potential Components of Three Summer Squash (Cucurbita pepo L.) Cultivars
}

\author{
Alejo RODRÍGUEZ-BURGOS ${ }^{1}$, Armando CARRILLO-LÓPEZ ${ }^{1,2}$, Tomás \\ OSUNA-ENCISO ${ }^{3}$, Manuel BÁEZ-SAÑUDO $^{3}$, Adriana SAÑUDO-BARAJAS $^{3}$, \\ Rosalba CONTRERAS-MARTÍNEZ ${ }^{3}$, José de Jesús ZAZUETA-MORALES ${ }^{1}$, \\ Misael Odín VEGA-GARCÍA ${ }^{1}$, Dolores MUY-RANGEL ${ }^{3 *}$
}

\author{
${ }^{1}$ Universidad Autónoma de Sinaloa. Facultad de Ciencias Quimico-Biológicas, Programa Regional de Posgrado en Biotecnologia, 80013 Culiacám, \\ México;arodriguez@uas.edu.mx; acarrill@uas.edu.mx \\ ${ }^{2}$ Universidad Autónoma de Sinaloa. Facultad de Ciencias Quimico-Biológica, Posgrado en Cienciay Tecnología de Alimentos 80013 Culiacám \\ México; acarrill@uas.edu.mx;zazuetaj@uas.edu.mx;mvega@uas.edu.mx \\ ${ }^{3}$ Centro de Investigación en Alimentación y Desarrollo, AC Unidad Culiacán, Carretera a Eldorado Km 5.5 Campo el Diez, 80110 Culiacán, Sinaloa, \\ México; osuna@ciad.mx;mabaez@ciad.mx; adriana@ciad.mx; rcontreras@ciad.mx; mdmuy@ciad.mx(*correspondingauthor)
}

\begin{abstract}
Summer squash fruit is a horticultural crop that possesses a very short postharvest life due to its high rates of metabolism and transpiration along with a low cuticle resistance exhibited mainly when the fruit is harvested at horticultural maturity. This research was realized following the fruit growth of the summer squash cultivars: 'Enterprise', 'Pascola' and 'Hurakan F1', whose seeds were germinated in polystyrene trays and their seedlings were subsequently transferred to pots for optimum growth under greenhouse conditions. Fruits were sampled at 3, 5, 7 and 9 days after anthesis (DAA). Physical (weight, diameter, and length of fruit), chemical ( $\mathrm{pH}$, titratable acidity and total soluble solids), hydric status (water, osmotic and pressure potentials), and histological analysis were done. The highest number of fruits having marketing quality were shown in both 'Pascola' and 'Hurakan F1' cultivars at 7 DAA, whereas, in 'Enterprise' was shown at 9 DAA. Marketing quality fruits from the three cultivars showed similarities on $\mathrm{pH}$ (about 6.6), titratable acidity (TA) decreases in 'Enterprise' and 'Hurakan F1', whereas total soluble solids (TSS) decreases in 'Pascola' and 'Hurakan F1' ( $\mathrm{p} \leq 0.5)$. From 3 to 9 DAA, in all cultivars, the water potential was close to -1.0 MPa, the osmotic potential showed an increasing pattern ranging between -1.59 and $-1.15 \mathrm{MPa}$, and the pressure potential remained in the positive range. Tissue water stability was histologically related to a well-defined parenchyma tissue showing thin-walled, polygonal, intact and turgid cells during fruit growth.
\end{abstract}

Keywords: histological analysis, F1 hybrids, pressure potential, osmotic potential, summer squash genotypes

\section{Introduction}

Mexico is among the ten major squash (Cucurbita pepo L.) producing countries all over the world, with about 400,000 tons produced in 2013 . Sinaloa State contributed with the $11.2 \%$ of the national production from which the $93.92 \%$ were summer squash type (SIAP-SAGARPA, 2014). Squash fruit is rich in vitamins, minerals with low calorie supply (Danilchenko et al., 2001). It is well known about the growth behaviour exhibited for squash fruit according to Sedano et al. (2005) who reported that squash fruit of 'Tala' variety (Cucurbita pepo L.) showed a sigmoid-like continuous growth behaviour, a high concentration of solids and good organ integrity in the stage of maximum development. However, this crop shows a high perishability and may be damaged at harvest and/or suffer rotting during postharvest, which can drastically reduce its quality and marketability period (Fornaris, 2012). Crop sensitivity during postharvest handling is closely related to the immature status at harvest (Cantwell and Suslow, 2004) providing high metabolic activity and high transpiration rate (Bafeel and Moftah, 2008). In the case of squash (Cucurbita maxima D.), texture is influenced by changes in water content (Sunil et al., 1999). Fruit quality loss is often expressed in terms of firmness loss and appearance (wilt symptoms) along with changes in tissue water status (Brew et al., 2006). Therefore, it is very 
important to take good care of the quality status during fruit development. Water status of fruit during pre-harvest, along with chemical changes has been scarcely studied in summer squashes. Beecher et al. (2001) stated that $\Psi_{\mathrm{p}}$ is responsible for providing turgor/freshness to the plant tissues. For such a purpose, $\Psi_{\mathrm{p}}$ must be kept higher than zero as long as possible in both pre- and postharvest. For that, summer-squash fruits must be harvested at a $\Psi_{\mathrm{p}}$ level higher than zero along with a proper fruit edible quality in order to keep turgor for longer after harvest. Hence, this work aimed in monitoring physical, chemical and water status changes (water-, osmotic- and pressure potential) of fruits for three different squash cultivars during its growth till horticultural maturity.

\section{Materials and Methods}

\section{Materials and general crop conditions}

Experiments were carried out in greenhouses at "Centro de Investigación en Alimentación y Desarrollo, A.C, Unidad Culiacán" (CIAD) in 2012. Three summer squash cultivars were studied: 'Enterprise', 'Pascola' and 'Hurakan F1'. The 'Enterprise' cultivar whose seeds were purchased from Syngenta is a yellow coloured straightneck type; 'Pascola' cultivar (seeds from Syngenta) is a dark green coloured zucchini type, whereas 'Hurakan F1' is a gray zucchini type according with the supplier (Harris Moran), with very similar characteristics to the green-grayish coloured vegetable-marrow type according with the classification of Paris (1986). The three summer squash hybrid seeds varieties were cultivated under controlled environmental conditions (average temperature: $19.8{ }^{\circ} \mathrm{C}$ and $\mathrm{RH}: 64.8 \%$ ) and a drip irrigation system. At the beginning of pollination, female flowers were labeled for development tracking. During growth, five fruits were randomly and manually collected at 3, 5,7 and 9 days after anthesis (DAA) and measured in length $(\mathrm{mm})$, diameter $(\mathrm{mm})$ and weight (g) for each squash cultivar. In the same manner, $\mathrm{pH}$, titratable acidity, total soluble solids, water- $\left(\Psi_{\mathrm{w}}\right)$, osmotic- $\left(\Psi_{\mathrm{s}}\right)$ and pressure potential $\left(\Psi_{\mathrm{p}}\right)$ were determined. Finally, a histological analysis was also performed by observing fruit tissues (epicarp and mesocarp) with optical microscopy.

\section{Dynamics of crop growth}

Squash seeds were placed them in 128-hole polystyrene trays and incubated in a climatic chamber Barnstead Iowa 52001 (USA) at $25 \pm 1^{\circ} \mathrm{C}$ during eight days until reaching $85 \%$ of germination. Afterwards, the seedlings were placed in a high technology greenhouse for 17 days. When plants showed three true leaves they were immediately planted in a composed substrate of coconut fiber and perlite (75:25) in two rows of 30 plants for each hybrid. The nutrient solution consisted of $13.0 \mathrm{Meq} \mathrm{NO}_{3}$, $1.5 \mathrm{H}_{2} \mathrm{PO}_{4}, 7.0 \mathrm{SO}_{4}, 7 \mathrm{~K}, 9.0 \mathrm{Ca}$ and $4.0 \mathrm{Mg}$, properly applied by the drip irrigation system every 40 minutes at a rate of 2 Liters per day, with an electrical conductivity of $2 \mathrm{dS} \mathrm{m}^{-1}$, at $64.8 \% \mathrm{RH}$ (average) and $19.8^{\circ} \mathrm{C}$. Pollination was enhanced by releasing bees (Apis mellifera) into the greenhouse. The fruit collection was started at three days after anthesis for growth dynamic measurement.

\section{Chemical analysis}

The $\mathrm{pH}, \mathrm{TA}$ and TSS were determined according to AOAC (2000). Ten grams of the sample were blended in $50 \mathrm{ml}$ of distilled water and filtered through an organza cloth. The $\mathrm{pH}$ and titratable acidity were measured employing an automatic titrator Metler Modelo T-50 (Mexico) using 50-mL aqueous extracts from the fruit samples. Firstly, $\mathrm{pH}$ was read and thereafter sample were titrated with $0.1 \mathrm{~N}$ sodium hydroxide until reaching a $\mathrm{pH}=8.2$. TA data were reported in $\%$ of malic acid. TSS were analyzed in filtered drops using a refractometer ABBE Leyca Mark II (Buffalo, NY) and expressed in Brix degrees.

\section{Water $\left(\Psi_{w}\right)$, Osmotic $\left(\Psi_{s}\right)$ and pressure $\left(\Psi_{p}\right)$ potential}

The $\Psi_{\mathrm{w}}$ of the tissue was measured using the constant volume method (Shibairo et al., 1997). Three fruits were selected and four cylinders of mesocarp tissue $(20 \times 25 \mathrm{~mm})$ were obtained, from each fruit. The cylinders were initially weighed and then immersed in four sucrose solution $(0.10,0.20,0.30$ and 0.40 Molal) for 110 minutes. Subsequently, the excess of water on tissue surface was removed from all samples using paper towels and weighed again on a digital scale AND GFH2000. All data were reported in terms of percentage of weight loss or weight gain because of all samples currently show some variation respect to their initial weight due to the differences in $\Psi_{\mathrm{w}}$ between samples and sucrose solutions. Weight loss or weight gain versus $\Psi$ s was registered and the intersection at zero (neither weight gain nor weight loss) was determined as well. Previously, the $\Psi_{s}$ for all sucrose solutions were calculated using the following equation:

$$
\Psi_{s=-C i \mathrm{RT}}
$$

$$
\begin{aligned}
& \text { Where: } \\
& C=\text { molal concentration } \\
& i=\text { ionization constant } \\
& \mathrm{R}=\text { gas constant }\left(0.00831 \mathrm{~kg} \mathrm{Mpa} \mathrm{mol}^{-1} \mathrm{~K}^{-1}\right) \\
& \mathrm{T}=\text { temperature }\left(\text { in }^{\circ} \mathrm{K}\right) ;
\end{aligned}
$$

Since $\Psi_{\mathrm{w}}=\Psi_{\mathrm{s}}+\Psi_{\mathrm{p}}$, and because of $\Psi_{\mathrm{p}}$ for a solution at atmospheric pressure is zero, then for the sucrose solutions $\Psi_{s}=$ $\Psi_{\mathrm{w}}$ and according to this, $\Psi_{\mathrm{w}}$ of the sample is known when neither gain nor loss of weight is observed on samples. In this point the $\Psi_{\mathrm{s}}$ of the solution correspond to $\Psi_{\mathrm{w}}$ of the samples (Salisbury and Ross, 2000).

The direct $\Psi_{s}$ of the tissue was determined using a vapor pressure osmometer (5520 Wescor USA) following Turner's methodology (1981). Ten $\mu \mathrm{L}$ of fruit sap was added in filter paper $\left(0.32 \mathrm{~cm}^{2}\right)$ and placed it in a reception chamber. All sap was obtained from frozen tissue samples $\left(-20^{\circ} \mathrm{C}\right)$ which were defrosted at room temperature in order to get cell-wall rupture and set the turgor potential to zero. The calibration of the equipment was done with osmotic potential solutions of 290, 1000 and $100 \mathrm{mmol} \cdot \mathrm{kg}^{-1}$ of $\mathrm{NaCl}$ (results were expressed in mmol $\left.\mathrm{kg}^{-1}\right)$. Conversion of molality to osmotic potential was carried out using the Van't Hoff equation: $\Psi_{s=}=-C i \mathrm{RT}$, (Salisbury and Ross, 2000), where the ionization constant, $\mathrm{i}$, is 1.8 for $\mathrm{NaCl}$. The $\Psi_{\mathrm{p}}$ was calculated according to Turner (1981), as the difference among water potential and osmotic potential $\left(\Psi_{\mathrm{p}}=\right.$ $\left.\Psi_{\mathrm{w}}-\Psi_{\mathrm{s}}\right)$. All these variables were analyzed in freshly cut fruits at 3 , 5,7 and 9DAA.

\section{Histological analysis}

For squash tissue fixation, $1-\mathrm{cm}^{3}$ pieces of pericarp (mesocarp with epicarp) were cut, and placed them in a jar with $50 \mathrm{~mL}$ of FAA fixative solution $(500 \mathrm{~mL}$ ethanol $96 \%, 50 \mathrm{ml}$ acetic acid, 
422

$100 \mathrm{ml}$ formaldehyde and $350 \mathrm{ml}$ of water). Afterwards, samples were rinsed with tap water, and dried with alcohol and xylene solutions at different concentrations. Dehydrated tissues were embedded in paraffin and finally, sections of $10 \mu \mathrm{m}$ thick were made with a rotary microtome LEICA RM 2125 RT China. All sectioned samples were placed in glass microscope slides using adhesive Haupt (1\% gelatin, $13 \%$ glycerol, $2 \%$ phenol and water). Furthermore, they were stained with safranin and solid Green dyes, covered with a coverslip and mounted with Canadian balsam for getting permanent preparations (Osuna et al., 2008). At last, cuts were observed in optical microscope 1122 100 Zeiss ${ }^{\circledR}$ Axiostar Mexico. Cell development was followed in epicarp and mesocarp tissues.

\section{Experimental design}

Experiments were conducted under a two-factor randomized design (time and type of squash). Time was set at four levels: 3, 5, 7 and 9 DAA and the type of squash were the cultivars: 'Enterprise', 'Pascola' and 'Hurakan F1'. Means were subjected to comparison according to the Tukey mean separation test $(\alpha=0.05)$ (MINITAB 2004, version 14.0).

\section{Results and Discussion}

\section{Dynamics of crop growth}

All of the studied cultivars reached horticultural maturity in 42-58 days after sowing (DAS). The whole period to achieve horticultural maturity was composed by a germination stage of 8 days, a vegetative growth stage of 27-35 days and a fruit growth stage of 7-9 days. The fruit growth (measured by weight, length and diameter) showed a sigmoidal behaviour (Fig. 1). Lin and Varner (1991) reported that the growth of a typical zucchini fruit showed a typical sigmoid growth pattern when measured both circumference and length against time. Salisburi and Ross (2000) reported that a sigmoid growth curve is exhibited by numerous annual plants or individual parts of plants and that fruit growth is made up by consecutive stages: cell division, cell elongation and seed formation. Also, Sedano et al. (2005) reported a sigmoidal behaviour in dry matter accumulation for the organs and the whole plant of Cucurbita pepo L. (hybrid 'Tala'). Furthermore, in a growth dynamic study for 8 hybrids of 'gray zucchini', Lopez et al. (2011) reported a sigmoidal pattern for the growth of the whole plants for all hybrids. In this study, 'Pascola' and 'Hurakan F1' showed their greatest size at 7 DAA, whereas the 'Enterprise' cultivar showed it at 9DAA (Fig. 1). 'Enterprise' cultivar showed a slightly earliness in full flowering and fruit development initiation but commercial size was achieved two days later than 'Pascola' or 'Hurakan F1'. The highest number of fruits per plant having marketing quality was shown at 7 DAA in 'Pascola' and 'Hurakan F1' cultivars, whereas at 9DAA for 'Enterprise' (Data not shown). All cultivars developed a cylindrical shape with diameters around $46 \mathrm{~mm}$ and length around $168 \mathrm{~mm}$ in their horticultural maturity (Fig. 1). In the study of growth dynamic for the 8 hybrids of 'gray zucchini', Lopez et al. (2011) reported a value of $125 \mathrm{~mm}$ reached in 5-7 DAA, as the greatest fruit length for all the studied materials ('Terminator', 'Lolita', 'WA9041', 'Tala', 'Dolarzini', 'Hurakan', among others). This value of fruit length resulted shorter than any of the cultivars of this study which ranged from 142 to $173 \mathrm{~mm}$. In relation to fruit diameter, the gray-zucchini hybrids reached similar values to data of this study at 7 DAA, all of them around $44 \mathrm{~mm}$. All of the three cultivars exhibited their completely flowering period from 38 to 52 DAS. This reproductive period was clearly made up by three phases based on the predominance of flower sex: The first, with the highest number of masculine flowers (about $80 \%)$, followed by a phase of uniformity in percentage (50:50), and at the end the female flowers predominated (about $80 \%)$. The flowering initiation was at the 38, 38 and 40 DAS for 'Enterprise', 'Hurakan F1' and 'Pascola', respectively, whereas the full flowering was at 40, 42 and 43 for 'Enterprise', 'Hurakan F1' and 'Pascola', respectively. The flowering initiation is the number of days elapsed after sawing when the $50 \%$ of total number of plants plus one exhibits at least one flower, whereas full flowering is when the $100 \%$ of plants had developed at least one flower).

\section{Chemical characteristics}

At horticultural maturity (HM), all of the studied cultivars showed similar levels of $\mathrm{pH}$, ranging between 6.64 and 6.67. TA was lower ( $\mathrm{p} \leq 0.05)$ for 'Enterprise' $(0.043 \%)$ versus 'Pascola' $(0.064 \%)$ or 'Hurakan F1' (0.061\%). However, TA was not different between 'Pascola' and 'Hurakan F1' (Table 1).

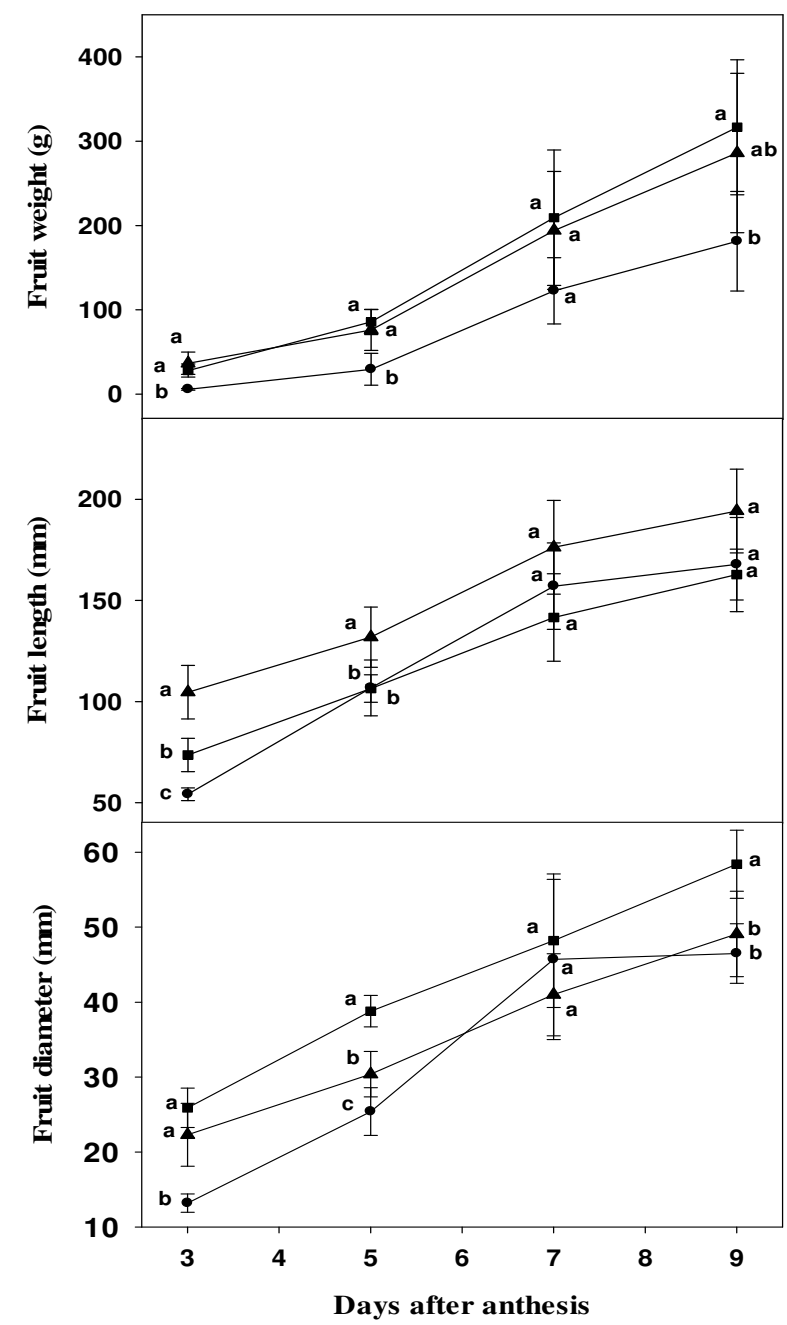

Fig. 1. Fruit weight, length and diameter in three summer squash cultivars during growth

'Enterprise' (•), 'Pascola' ( $(\boldsymbol{\Lambda})$ and 'Hurakan Fl' $(-$ ). Data are means of five replicates \pm standard deviation. Differentletters among cultivars denote significant differences (Tukey test, $\mathrm{P}<0.05$ ). 
Table 1.Physicochemical characteristics of three summer squash cultivars

\begin{tabular}{|c|c|c|c|c|}
\hline Cultivar & Days after anthesis (DAA) & $\mathrm{pH}$ & $\begin{array}{c}\text { Titratable } \\
\text { Acidity }\end{array}$ & Total soluble solids, in ${ }^{\circ}$ Brix \\
\hline \multirow[t]{4}{*}{ 'Enterprise' } & 3 & $6.62^{a, x} \pm 0.07$ & $0.071^{a, y} \pm 0.003$ & $5.40^{a, x} \pm 0.01$ \\
\hline & 5 & $6.60^{a, x} \pm 0.03$ & $0.071^{\mathrm{a}, \mathrm{x}} \pm 0.003$ & $5.55^{a, x} \pm 0.30$ \\
\hline & 7 & $6.64^{a, x} \pm 0.05$ & $0.049^{\mathrm{b}, \mathrm{x}} \pm 0.006$ & $4.95^{a, x} \pm 0.30$ \\
\hline & $9(\mathrm{HM})$ & $6.67^{\mathrm{a}, \mathrm{y}} \pm 0.04$ & $0.043^{\mathrm{b}, \mathrm{x}} \pm 0.005$ & $4.50^{a, x} \pm 0.60$ \\
\hline \multirow[t]{4}{*}{ 'Pascola' } & 3 & $6.79^{a, y} \pm 0.02$ & $0.062^{a, x} \pm 0.004$ & $5.70^{a, x, y} \pm 0.35$ \\
\hline & 5 & $6.79^{a, y} \pm 0.02$ & $0.062^{a, y} \pm 0.003$ & $5.70^{a, x} \pm 0.35$ \\
\hline & 7 (HM) & $6.64^{a, x} \pm 0.06$ & $0.064^{a, y} \pm 0.004$ & $4.65^{b, x, y} \pm 0.30$ \\
\hline & 9 & $6.63^{a, y} \pm 0.02$ & $0.049^{b, x} \pm 0.003$ & $3.60^{b, y} \pm 0.01$ \\
\hline \multirow[t]{4}{*}{ 'Hurakan F1' } & 3 & $6.75^{\mathrm{a}, \mathrm{y}} \pm 0.01$ & $0.072^{a, y} \pm 0.003$ & $6.15^{a, y} \pm 0.30$ \\
\hline & 5 & $6.77^{a, y} \pm 0.05$ & $0.046^{\mathrm{b}, \mathrm{z}} \pm 0.002$ & $5.70^{a, x} \pm 0.35$ \\
\hline & 7 (HM) & $6.65^{a},{ }^{x} \pm 0.03$ & $0.060^{a, x y} \pm 0.005$ & $4.05,{ }^{b, y} \pm 0.30$ \\
\hline & 9 & $6.56^{b, x} \pm 0.03$ & $0.044^{\mathrm{b}, \mathrm{x}} \pm 0.005$ & $3.45^{b, y} \pm 0.30$ \\
\hline
\end{tabular}

Different lowercase letters $(\mathrm{a}, \mathrm{b})$ between DAA for each cultivar denote significant differences (Tukey test, $\mathrm{P}<0.05)$.

Different lowercase letters $(x, y, z)$ between cultivars for the same DAA denote significant differences (Tukey test, $\mathrm{P}<0,05$ ).

$\mathrm{HM}=$ Horticultural maturity

\section{Total Soluble Solids (TSS)}

At horticultural maturity, TSS showed similar levels ranging from 4.05 to $4.65^{\circ} \mathrm{Brix}$, among cultivars. These chemical properties can be described as it was reported by Kader (2002) for fruits harvested at horticultural maturity. He mentioned that these fruits possess chemical characteristics close to neutrality and are low in sweetness. Derossi $e t$ al. (2011) reported approximate values for $\mathrm{pH}(6.42 \pm 0.16)$ and for TSS ( $\left.4.8^{\circ} \mathrm{Brix}\right)$ from a zucchini-type squash. On the other hand, it seems that although with similar $\mathrm{pH}$ values, pumpkins or winter squashes are sweeter than zucchini type judging by the higher ${ }^{\circ} \mathrm{Brix}$ in their fruits. Zinash $e t$ al. (2013) reported for 20 accessions of fresh pumpkin grown in Ethiopia, a $\mathrm{pH}$ of $6.64 \pm 0.32$, and a TSS of $6.7^{\circ} \pm 1.5^{\circ} \mathrm{Brix}$. In the same manner, Valenzuela $e t$ al. (2011) reported for a Winter squash (Cucurbita moschata D.) a pH of $6.77 \pm 0.7$, a TA of $0.04 \pm 0.04$ and TSS of $6.4 \pm 2.2$. The difference in TSS is believed to be due to differences in the developmental stages at harvest between summer and winter squashes. The harvest stage for winter squashes is carried out at their fully mature fruit stage at which TSS reaches its maximum potential, whereas zucchini type squashes are harvested at horticultural maturity, which is an immature fruit stage of development. During fruit growth, $\mathrm{pH}$ kept constant for the three cultivars. TA decreases in 'Enterprise' and 'Hurakan F1', whereas TSS decreases in 'Pascola' and 'Hurakan Fl' $(\mathrm{p} \leq 0.5)$.

\section{Water,-pressure-and osmoticpotential}

The $\Psi_{\mathrm{w}}$ was measured during fruit growth at 3,5,7 and 9 DAA. The horticultural maturity was reached at $7 \mathrm{DAA}$ for both 'Pascola' and 'Hurakan F1', and at 9DAA for 'Enterprise'. The $\Psi_{w}$ for all the cultivars was kept with no significant changes during fruit growth measured until harvest at horticultural maturity (Fig. 2). $\Psi_{\mathrm{w}}$ oscillated around $-0.99 \mathrm{MPa}$ whereas $\Psi_{\mathrm{p}}$ showed always positive values, however its tendency was decreasing since the beginning, lowering from 0.59 to 0.15 , from 0.49 to 0.27 and from 0.41 to 0.19 MPa for, 'Enterprise', 'Pascola' and 'Hurakan F1', respectively. Beecher et al. (2001) stated that $\Psi_{\mathrm{p}}$ is responsible for providing cell shape and tissue stiffness due to the pressure that water exerts on cell walls. However, $\Psi_{\mathrm{p}}$ must be kept higher than zero as long as possible in both pre- and postharvest in order to keep tissue-freshness/turgor for longer. Irremediably, plant tissues lose weight in postharvest storage and $\Psi_{\mathrm{p}}$ tends to drop under zero. Urias et al. (2012) reported cell plasmolysis ( $\Psi_{\mathrm{p}}$ less than zero) when squashes had lost $6 \%$ of their weight after the third day of storage at $20^{\circ} \mathrm{C}$ and at the sixth day of storage at $10{ }^{\circ} \mathrm{C}$. On the other hand, $\Psi_{s}$ showed an increasing pattern rising from -1.59 to 1.15, from -1.49 to -1.27, from -1.41 to - 1.19 MPa, for 'Enterprise', 'Pascola' and 'Hurakan F1', respectively. This behavior in $\Psi_{s}$ suggests that the supply of water and solids from the plant (source) to the fruit (sink) exhibited an increased water/solids ratio during fruit growth, The increased $\Psi_{s}$ along with the decreasing TSS levels during fruit growth can be seen as a cell solute dilution due to an increased water absorption by the cell and the concomitantly cell growth by enlargement as suggested by Bidwell (1979). The decreasing $\Psi_{\mathrm{p}}$ is also explainable by cell enlargement. When harvested at horticultural maturity, all the cultivars showed a turgid texture with $\Psi_{\mathrm{p}}$, of $0.15,0.27$ and 0.19 for 'Enterprise', 'Pascola' and 'Hurakan F1', respectively. 'Pascola' and 'Hurakan F1' cultivars were evaluated at 9 DAA (2 days after horticultural maturity) and it was found that $\Psi_{\mathrm{p}}$ decreased slightly in 'Pascola' (reaching 0.21) with respect to 7 DAA, whereas in 'Hurakan F1', $\Psi_{p}$ decreased approximating to zero $(0.06)$. These latter results suggest that 'Pascola' fruits might be harvested at 9 DAA instead of at 7 DAA provided that quality characteristics (less TSS) do not become a commercial drawback. Harvesting 'Hurakan F1' at or after 9 DAA must be avoided. A $\Psi_{\mathrm{p}}$ higher from zero at harvest is also desirable in summer squash due to its high susceptibility to suffer weight loss and shriveling on postharvest storage according to Sherman et al. (1985).

\section{Histology}

Fruit ground tissue for all cultivars at all growth stages showed a typical parenchyma tissue. All samples showed thin-walled, polygonal, intact and turgid cells. However, cells from all cultivars at 3 DAA were smaller than at 7 DAA. This clearly suggest that mesocarp cells at 3 DAA were at their proliferation stage (in cell division) and afterwards the cells experienced enlargement, as can be seen at 7 DAA for all cultivars. A similar behaviour was reported by Higashi $e t$ al. (1999) for two melon genotypes. In this study the cell enlargement was concomitant with a drop in $\Psi_{\mathrm{p}}$ and an increase in $\Psi_{s}$, whereas $\Psi_{w}$ kept unchanged. Although $\Psi_{\mathrm{p}}$ exhibited a drop, its level was always kept in the positive range allowing the tissue to stay turgid at harvest and not so close to zero at which incipient plasmolysis is presented in plant tissues. From Fig. 3 is also clear that cells outward the mesocarp were smaller than cells inward. Epicarp was clearly thinner at 3 DAA than at 7 DAA in 'Enterprise' and 'Pascola' cultivars. 


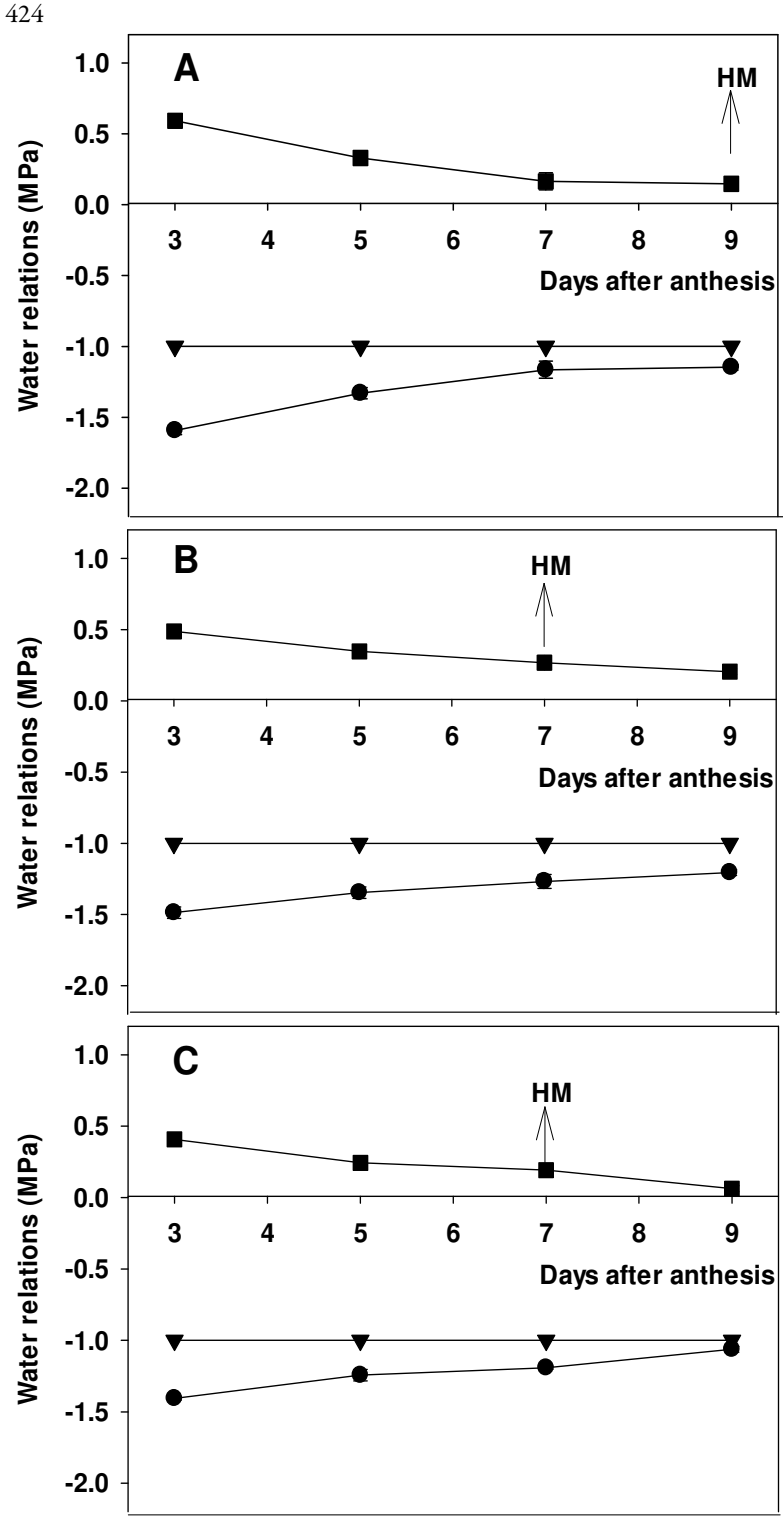

Fig. 2. Water $(\boldsymbol{\nabla})$, osmotic $(\bullet)$ and pressure potential $(\boldsymbol{\square})$ for three summer squash cultivars during growth: 'Enterprise' (A), 'Pascola' (B) and 'Hurakan Fl' (C).HM= Horticultural maturity.

\section{Conclusions}

'Enterprise' cultivar showed a slightly earliness in full flowering and fruit development initiation but its commercial size was achieved later than 'Pascola' and 'Hurakan F1' (after 2 days). However, since 'Enterprise' showed unchanged levels in $\mathrm{pH}$, TA, TSS and pressure potential during the period from 7 to 9 DAA, these results suggest that 'Enterprise' fruits might be harvested at $7 \mathrm{DAA}$ instead of at $9 \mathrm{DAA}$ provided that smaller fruit sizes do not become a commercial drawback. All of the three cultivars showed a sigmoidal pattern of growth mainly when measured by whole fruit weight. Chemical (mainly TSS) and physicochemical $\left(\Psi_{\mathrm{p}}\right)$ variables decreased concomitantly to the increment in osmotic potential, cell enlargement and fruit size suggesting a dilution of solutes into tissue cells during fruit growth.
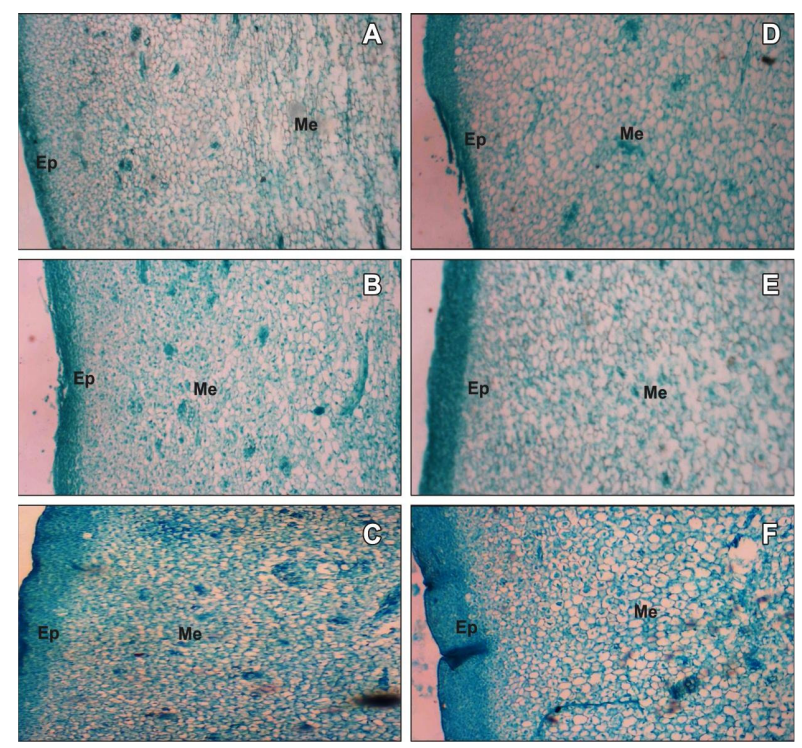

Fig. 3. Fruit transect microphotography for 'Enterprise' (top) 'Pascola' (middle) and 'Hurakan F1' (bottom) summer squash cultivars at 3 (A, B, C) and 7 (D, E, F) days after anthesis. Epicarp (Ep), Mesocarp (Me). Focus: $4 \mathrm{X}=40$ increases

\section{Acknowledgements}

Authors thank to Oscar Martínez for technical assistance. This work was supported by CONACYT-MEXICO by granting a PhD scholarship.

\section{References}

AOAC (2000). Association of Official Analytical Chemists. Official Methods of Analysis (17th Ed). Washington DC, USA.

Bafeel S, Moftah A (2008). Physiological response of eggplant grown under different irrigation regimes to antitransplant treatments. Saudi Journal of Biological Science 15(2):259-267.

Beecher TM, Magan N, Burton KS (2001). Water potentials and soluble carbohydrate concentration in tissues of freshly harvested and stored mushrooms' (Agaricus bisporus). Postharvest Biology and Technology 22:121-131.

Bidwell RGS (1979). Plant physiology. McMillan Publishing Co (2nd Ed), New York.

Brew BS, Berry AD, Sargent SA, Shaw NI, Cantliffe DJ (2006). Determination of optimum storage conditions for 'baby' summer squash fruit (Cucurbita pepo). Proceeding of the Florida State Horticultural Society 119:343-346.

Cantwell, Marita and Suslow Trevor V (2004). Calabaza: zapallo de invierno. Recomendaciones para mantener la calidad poscosecha [Pumpkin \& winter squash: Recomendations for maintaining postharvest quality] Postharvest Technology. Research Information Center. Deparment of Vegetables Crops. University of California, Davis.

Danilchenko H, Paulauskiene A, Marciukaite G (2001). The research of technological characteristics of pumpkin cultivars. SodininkystėDaržin 20:196-204 
Derossi AT, Pilli MP, La Penna C, Severini (2011). pH reduction and vegetable tissue structure changes of zucchini slices during pulsed vacuum acidification. Food Science and Technology 44:1901-1907.

Fornaris RG (2012). Conjunto tecnológico para la producción de calabaza, Cosecha y Manejo Poscosecha [Technological ensemble for producing squash, Harvest and Postharvest Handling]. Estación Experimental Agrícola, Colegio de Ciencias Agrícolas, Recinto Universitario de Mayagüez, Universidad de Puerto Rico. Publicación No. 155.

Higashi K, Hosoya K and Ezura H (1999). Histological analysis of fruit development between two melon (Cucumis melo L. reticulatus) genotypes setting a different size of fruit. Journal of Experimental Botany 50(339):1593-1597.

Kader A (2002). Postharvest technology of horticultural crops. University of California Agriculture and Natural Resources $\left(3^{\text {rd }} \mathrm{Ed}\right)$, Oakland CA.

López SJL, Ortiz QA, Sánchez HC (2011). Diferencias en Acumulación de Biomasa y Rendimiento en Hibridos Comerciales de Calabacita Gris. Adaptación de Variedades de Hortalizas [Differences in biomass accumulation and yield of commercial hybrids of gray zucchini. Adaptation of varieties of vegetables] Retrieved 2014 Jul 31 from http://www.hortalizas.com/articulo/26049/adaptación de variedades.

Lin LS, Varner JE (1991). Expression of Ascorbic Acid Oxidase in Zucchini Squash (Cucurbita pepoL.). Plant Physiology 96:159-165.

MINITAB (2004). Version 14.0. Meyer RK, Krueger DD - Version of OMNITAB, a statistical analysis program by NIST.

Osuna ET, Valenzuela RG, Muy RD, Gardea BA, Villareal RM (2008). Expresión del sexo y anatomía floral del litchi (Litchi chinensis Sonn.) [Sex expression and flower anatomy of litchi (Litchi chinensis Sonn.)]. Revista Fitotecnia Mexicana 31:51-56.

Paris HS (1986). A proposed subspecific classification for Cucurbita pepo. Phytologia 61: 133-138.

Salisbury, Frank B, Ross CW (2000). Fisiología de las plantas [Plant Physiology]. Thompson Editores, Spain.
Sedano CG, González HVA, Engleman EM, Villanueva VC (2005). Dinámica del crecimiento y eficiencia fisiológica de la planta de calabacita [Growth kinetics and physiological efficiency of zucchini plants]. Revista ChapingoSerie Horticultura 11:291-297.

SIAP-SAGARPA (2014). Servicio de Información Agroalimentaria y Pesquera - produccion agrícola de calabacita, 2014. Retrieved 2014 Jul 31 from http://www.siap.gob.mx/index. php?option $=$ com_wrapper\&view=wrapper\&itemid $=351$.

Sherman M, Elmstrom GW, Allen JJ (1985). Storage characteristics of three cultivars of yellow summer squash (Cucurbita pepo L). Proceedings of FloridaState Horticultural Society 98:216-218.

Shibairo SI, Upadhyaya MK, Toivonen PM (1997). Postharvest moisture loss characteristics of carrot (Daucus carota L.) cultivars during shortterm storage. Scientia Horticulturae 71(1-2):1-12.

Sunil, Ratnayake RM, Hurst PL, Melton LD (1999). Texture and the cell wall polysaccharides of buttercup squash 'Delica' (Cucurbita maxima). NewZealand Journal of Horticultural Science 27:133-143.

Turner NC (1981). Techniques and experimental approaches for the measurement of plant water status. Plant and Soil 58:339-366.

Urías OV, Muy RD, Osuna ET, Sañudo BA, Báez SM, Valdez TB,... Campos SJ (2012). Estado hídrico y cambios anatómicos en la calabacita (Cucurbita pepo L.) almacenada [Water status and anatomic changes in stored zucchini (Cucurbita pepo L.). Revista Fitotecnia Mexicana 35(3):221-228.

Valenzuela NJ, Zazueta MJ, Gallejos IJ, Aguilar GF, Camacho HI, Rocha G E, González LR (2011). Chemical and Physicochemical Characterization of Winter Squash (Cucurbita moschata D.). Notulae Botanicae Horti Agrobotanici Cluj-Napoca 39(1):3440.

Zinash A, Workneh TS, Woldetsadik K (2013). Effect of accessions on the chemical quality of fresh pumpkin. African Journal of Biotechnology 12(51):7092-7098. 